\title{
Isolation and characterization of mesenchymal progenitors derived from the bone marrow of goats native from northeastern Brazil ${ }^{1}$
}

\author{
Osmar Ferreira da Silva Filho', Napoleão Martins Argôlo Neto'I, Maria Acelina Martins de Carvalho ${ }^{\mathrm{III}}$, Yulla Klinger de \\ Carvalho $^{\text {IV }}$, Anaemilia das Neves Dinizv ${ }^{\text {, Laécio da Silva Moura }}{ }^{\mathrm{VI}}$, Carlos Eduardo Ambrósio ${ }^{\mathrm{VII}}$, Janaína Munuera Monteiro ${ }^{\mathrm{VIII}}$, \\ Hatawa Melo de Almeida ${ }^{\mathrm{IX}}$, Maria Angélica Miglino ${ }^{\mathrm{X}}$, Jacyara de Jesus Rosa Pereira Alves ${ }^{\mathrm{XI}}$, Kássio Vieira Macedo ${ }^{\mathrm{XII}}$, Andressa \\ Rego da Rocha ${ }^{\mathrm{XIII}}$, Matheus Levi Tajra Feitosa ${ }^{\mathrm{XIV}}$, Flávio Ribeiro Alves ${ }^{\mathrm{XV}}$
}

DOI: http://dx.doi.org/10.1590/S0102-86502014000800001

IFellow PhD degree, Postgraduate Program in Animal Science, School of Veterinary Medicine, Federal University of Piaui (UFPI), Teresina-PI, Brazil. Manuscript writing.

IIPhD, Assistant Professor, Department of Animal Science, School of Veterinary Medicine, UFPI, Bom Jesus-PI, Brazil. Flow cytometry procedures.

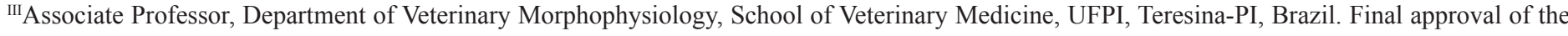
version to be published.

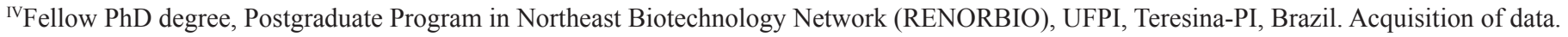

${ }^{\vee}$ Master, Division of Physiology, Department of Animal Science, State University of Piaui (UESPI), Uniao-PI, Brazil. Acquisition of data.

${ }^{\mathrm{VI}}$ Fellow Master degree, Postgraduate Program in Animal Science, School of Veterinary Medicine, UFPI, Teresina-PI, Brazil. Interpretation of data.

VIIPhD, Associate Professor, Department of Basic Sciences, Faculty of Animal Sciences and Food Engineering, Sao Paulo University (USP), Pirassununga-SP, Brazil. Conception and design of the study.

VIIIPostdoctoral Fellow, Teaching and Research Institute, Hospital Israelita Albert Einstein (HIAE), Sao Paulo-SP, Brazil. Flow cytometry procedures.

${ }^{\mathrm{IX}}$ Master, Division of Anatomy, Department of Animal Science, UESPI, Uniao-PI, Brazil. Interpretation of data.

${ }_{\mathrm{x}} \mathrm{PD}$, Full Professor, Department of Surgery, School of Veterinary, USP, Sao Paulo-SP, Brazil. Critical revision.

xIFellow Master degree, Postgraduate Program in Surgery, Federal University of Ceara (UFC), Fortaleza-CE, Brazil. Manuscript writing.

${ }^{\mathrm{XI}}$ Fellow Master degree, Postgraduate Program in Odontology, UFPI, Teresina-PI, Brazil. Microscopy examination.

${ }^{\mathrm{XII}}$ Fellow PhD degree, Postgraduate Program in Animal Science, School of Veterinary Medicine, UFPI, Teresina-PI, Brazil. Microscopy examination.

XIv Postdoctoral Fellow, Postgraduate Program in Animal Science, UFPI, Teresina-PI, Brazil. Critical revision.

${ }^{\mathrm{x}} \mathrm{PhD}$, Assistant Professor, Department of Veterinary Morphophysiology, School of Veterinary Medicine, UFPI, Teresina-PI, Brazil. Conception and design of the study, final approval of the version to be published.

\begin{abstract}
PURPOSE: To characterize bone marrow progenitors cells grown in vitro, using native goats from northeastern Brazil as animal model. METHODS: Ten northeastern Brazil native goats of both genders were used from the Piauí Federal University Agricultural Science Center's (UFPI) - Goat Farming Sector. Bone marrow aspirates where taken from the tibial ridge and seeded on culture plates for isolation, expansion and Flow Cytometry (expression markers - Oct-3/4, PCNA, Ck-Pan, Vimentina, Nanog).

RESULTS: Progenitor cells showed colonies characterized by the presence of cell pellets with fibroblastoid morphology. Cell confluence was taken after 14 days culture and the non-adherent mononuclear cell progressive reduction. After the first passage, $94.36 \%$ cell viability was observed, starting from $4.6 \times 10^{6} \mathrm{cell} / \mathrm{mL}$ initially seeded. Cells that went through flow cytometry showed positive expression for Oct-3/4, PCNA, Ck-Pan, Vimentina, and Nanog.
\end{abstract}

CONCLUSIONS: Bone marrow progenitor isolated of native goats from northeastern Brazil showed expression markers also seen in embryonic stem cells (Oct-3/4, Nanog), markers of cell proliferation (PCNA) and markers for mesenchymal cells (Vimentina and Ck-pan), which associated to morphological and culture growth features, suggest the existence of a mesenchymal stem cell (MSC) population in the goat bone marrow stromal cells studied.

Key words: Cell Culture Techniques. Cell Differentiation. Stem Cells. Flow Cytometry. Goats. 


\section{Introduction}

At first, studies on stem cells were restricted to progenitor cells committed to tissue renovation and differentiation, from resident cells in the same tissue ${ }^{1-3}$. However, the progress observed in the last few years, due to the biology of stem cells, has shown high levels of plasticity in certain types of cells ${ }^{4}$, demonstrating that cells from specific tissue $e^{5,6}$ have the capacity to give rise to cell lineages different of those of their primary source ${ }^{7-9}$.

Although studies are preliminary concerning the ability of stem cells to originate cells with a mature phenotype different from that observed in the tissue of origin ${ }^{10}$, they probably are the basis to the progress already seen in research associated to stem cell therapy ${ }^{11,12}$, as an alternative to intermediate mechanisms responsible for the regeneration of diverse tissues.

The search for suitable biological models ${ }^{13}$ has become increasingly important as a way to produce results closer to possible application to human medicine as well as improving the quality of animal life ${ }^{14}$. There are numerous animal models, such as rodents ${ }^{12,15}$, swine ${ }^{16}$ and canines ${ }^{17-19}$ that have been used in experiments related to cell therapies. Regarding such animals, outcomes were found in studies about neurodegenerative injuries ${ }^{12,13}$, as well as in attempts to use cell therapy as a way to treat cardiovascular diseases ${ }^{20}$.

Experiments with sheep were described for obtaining the main uses of stem cells/progenitor cells ${ }^{21,22}$. However, such potentialities have been little studied in the goat species. The goat herd, in Brazil, represents approximately 7.2 million animals, almost all of them found in Brazil's northeast. This scenario favors the introduction of the goat as an alternative potential model to obtain mesenchymal cells. In addition, the goat model finds a particular acceptance in Orthopedic Medicine fields ${ }^{23,24}$. Lechner et al. ${ }^{25}$ reported that goat joint injuries showed similarities to those observed in rheumatoid arthritis in humans.

Thus, the characterization of mesenchymal progenitors derived from the bone marrow of goats native to northeastern Brazil is a preliminary stage in the consolidation of a low-cost animal model to acquire cells whose differentiation potential may contribute to the understanding of the study of stem cells in preclinical studies and their role in tissue regeneration.

\section{Methods}

The experiment was conducted in accordance to the ethical principles for animal experimentation adopted by the Committee of Ethics in Animal Experimentation of the Federal
University of Piauí (Protocol n. 023/2010).

Ten northeastern Brazil native goats of both genders were used, between 1.0 and 1.5 years old, from the Piaui Federal University Agricultural Science Center's (UFPI) - Goat Farming Sector. The animals were taken for clinical and lab exams, in order to ensure the strict parameters demanded by the experiment, in accordance to Radostits, Gay and Hinchcliffet ${ }^{26}$. The animals were placed in $6 \mathrm{~m}^{2} /$ animal covered stalls, under a semi-extensive grazing system.

\section{Anesthetic procedures for bone marrow gathering}

The animals were sedated (meperidine hydrochloride, Agribands $\left.^{\mathrm{TM}}-5 \mathrm{mg} / \mathrm{Kg} / \mathrm{IM}\right)$ and then positioned in lateral recumbence, in order to shave the tibial ridge. The whole left pelvic member (chosen for gathering means) was cleaned ( $1 \%$ iodized alcohol, Impex ${ }^{\mathrm{TM}}$ ) - following the anesthetic block on the shaved area (lidocaine hydrochloride without vasoconstrictor; Xylestesin ${ }^{\mathrm{TM}}$, Cristália farma ${ }^{\mathrm{TM}}-5 \mathrm{mg} / \mathrm{Kg} / \mathrm{SC}$. The anesthesia was obtained from an association of Xylazine hydrochloride Rompum $^{\mathrm{TM}}$, Bayer do Brasil ${ }^{\mathrm{TM}}-1 \mathrm{mg} / \mathrm{Kg} / \mathrm{IM}$ ) and ketamine hydrochloride (KetalarTM, Pfizer do Brasil ${ }^{\mathrm{TM}}-40 \mathrm{mg} / \mathrm{Kg} / \mathrm{IM}$ ). The animals were kept under anesthesia (1\% Propofol, Fresofol, Fresenius $\mathrm{Kabi}^{\mathrm{TM}}-7 \mathrm{mg} / \mathrm{Kg} / \mathrm{IV}$ ) throughout the whole gathering procedure. After the surgical procedure, the puncture area was cleaned with Dakin liquid (6\% Sodium Hypochlorite and 5\% sodium bicarbonate), followed by oxytetracycline hypochlorite topic application associated to hydrocortisone (Terra-cortilim, Pfizer do Brazil) for six days.

\section{Bone marrow gathering}

Bone marrow aspirates were obtained from punctures in the tibial ridge $(9 \mathrm{~mL})$, using a 40 x 12 sterile hypodermic needle (18G), connected to a syringe filled with anticoagulant, ethylenediaminetetra-acetic acid (EDTA, Sigma-Aldrich). The collected sample was diluted in a buffered phosphate solution (PBS), concentration 1:1, and filtered to remove residual bone tissue. The filtered content was carefully transferred to a $15 \mathrm{~mL}$ tube (Falcon Tube $^{\mathrm{TM}}$, ACQuímica ${ }^{\mathrm{TM}}$ ) filled with ficoll solution (Ficoll Histopaque $^{\mathrm{TM}}$, Sigma ${ }^{\mathrm{TM}}$ ) and centrifuged at $2.000 \mathrm{rpm}$ for $25 \mathrm{~min}$. at $20^{\circ} \mathrm{C}$, to separate the contents, due to concentration gradient. The mononuclear cell fraction obtained was gently aspirated with an automatic pipette (Houston ${ }^{\mathrm{TM}}$ ) and immediately, washed two times with sterile PBS and centrifuged at $2.000 \mathrm{rpm}$ for $10 \mathrm{~min}$ at $4^{\circ} \mathrm{C}$. The supernatants were discarded, the pellet resuspended in 
14mL Dulbecco Medium Eagle Modified (DMEM) - low glucose, filled with $15 \%$ fetal bovine serum (SFB, Invitrogen Corporation), $1 \%$ non-essential amino acids, $1 \%$ L-glutamine, $1 \%$ antibiotic (TECMAL TE-399TM), then seeded in six-well plates (TPP) at 1.6 $\mathrm{x} 10^{6}$ cells/well, at $37^{\circ} \mathrm{C}$, in a $5 \% \mathrm{CO} 2$ humidified incubator and kept in semi-confluence to avoid differentiation.

\section{Cellular viability}

Fifty $\mu \mathrm{L}$ of the cells obtained in culture were diluted in $50 \mu \mathrm{L}$ Trypan Blue (Trypan Blue ${ }^{\mathrm{TM}}$, Sigma-Aldrich). The solution was homogenized and counted by hemocytrometer, as previously described by Meirelles and $\mathrm{Nardi}^{27}$.

The features of the isolated cultured cells were preserved by an enzymatic dissociation process by Trypsin-EDTA digestion, washed with PBS and resuspended in freezing environment (40\%SFB, 50\%DMEM low glucose and 10\% dimethylsulfoxide, Sigma-Aldrich). After this process, the cells were transferred to 10 freezing tubes (cryo-tubes, TPP) in $1.0 \times 10^{6}$ cells $/ \mathrm{mL}$ and placed in $-196^{\circ} \mathrm{C}$ liquid nitrogen.

\section{Flow cytometry}

Cells were submitted to flow cytometry in the fourth passage to ensure a sufficiently undifferentiated cell population for the accurate analysis of expression of their membrane proteins. Flow cytometry was performed using the Guava EasyCyte System (Guava Technologies). The cells were trypsinized and centrifuged at $1000 \mathrm{rpm}$ for 5 minutes and resuspended in PBS at a concentration of about $1 \times 10^{5}$ cells $/ \mathrm{mL}$. A $10^{5}$ cells/tube aliquot was used, equally diluted and resuspended in $200 \mu 1$ PBS, for further addition of each antibody, in the dark, for 45 minutes at room temperature. The cells were washed three times in PBS and resuspended in $0.20 \mathrm{ml}$ ice-cold PBS. PE anti-mouse secondary antibody (Guava Technologies) was used For the samples incubated with non-conjugated antibodies. The samples were incubated for 15 minutes, washed three times with PBS and resuspended in $2.20 \mathrm{ml}$ ice-cold PBS.

The flow cytometer was calibrated using non-marked cells. The cells were separated by forward scatter in order to eliminate debris. To eliminate a possible autofluorescence, parameters were adjusted so as to remove any contribution from marked cells. At least 9000 events were counted for each sample. The following markers were analyzed: OCT-3/4, PCNA, CKPAN, VIMENTINA, NANOG.

\section{Outcome analysis}

The cells obtained were analyzed by in vitro morphology and growth, photographed in an inverted light microscope (COLEMAN NIB-100 ${ }^{\mathrm{TM}}$ ) objective lens x10, x20 and x40, and the images were stored by an image capturing software (MTO Digital Color Camera ${ }^{\mathrm{TM}}$ ). Cells submitted to flow cytometry were evaluated by a graphic that shows the relative fluorescence found from each cell population in the samples studied.

\section{Results}

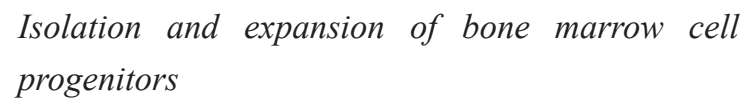

The mononuclear cell fraction obtained was highlighted in an interface between the plasma and Ficoll Histopaque ${ }^{\mathrm{TM}}$ solution and centrifugation then showed a $4 \times 10^{6}$ cells $/ \mathrm{mL}$ concentration. After seeding in culture, these cells showed a heterogeneous pattern in the first 24 hours, characterized by a population of cells adhering to the plastic bottom of the well (Figure 1A). There were also non-adherent cells in suspension, probably lymphocytes and macrophages, which were taken off during the consecutive PBS washes, $72 \mathrm{~h}$ after the beginning of culture (Figure 1A, B). Adherent progenitors were sequentially selected by the basal medium used. A homogeneous culture was obtained eight days of culture, with a progressively reduced amount of non-adherent cells. Such a process develops to create a cell monolayer, consisting of spindleshape cells that divided; they kept a cell-to-cell interaction and showed cytoplasmatic extensions parallel to each other (Figure 1C). When the cells reached $80 \%$ confluence (14 days culture), the first enzymatic dissociation was performed (P1) (Figure 1D). After 17 days culture, the cells showed homogeneous colonies that were fibroblastoid and confluent (Figure 1E). 

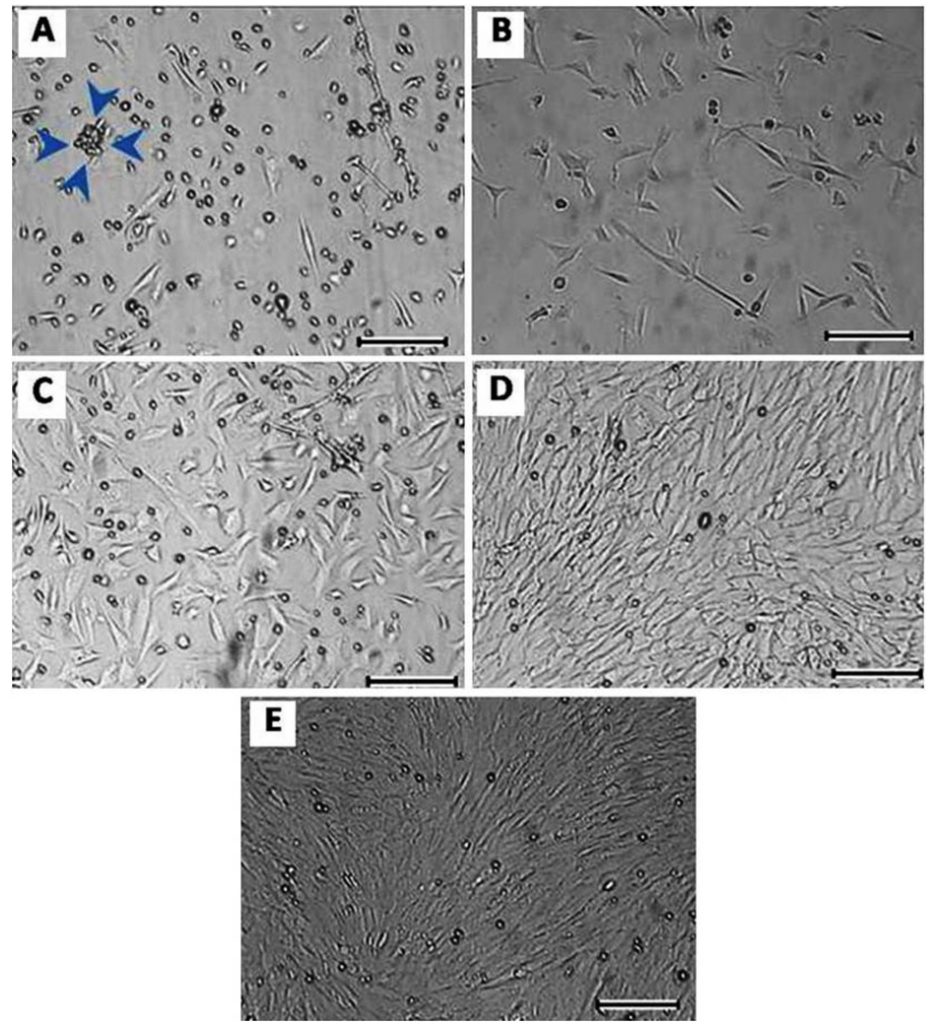

FIGURE 1 - Photomicrography of culture of goat bone marrow adherent cells. (A) Cells after 24 hours in culture. Note the non-adherent mononuclear cell cluster and the presence of cells already bonded to the culture plate, in a spindle shape. (B) Cells after the first PBS wash. Note the decrease in the amount suspended cells and the higher definition of the adherent mononuclear cells. (C) Cells after eight days culture presenting $60 \%$ confluence. Note the small amount of suspended non-adherent cells. (D) The $14^{\text {th }}$ culture day and (E) on the $17^{\text {th }}$ culture day, both with $80 \%$ confluence. Note the spindle shape pattern and the radial growth adopted during this particular phase. Rod: A-E $100 \mu \mathrm{m}$.

The average cell viability of the harvested cells was $99.45 \%$, and throughout the 49 days in culture a $97.72 \%$ average was maintained throughout all the passages (Figure 2). When expanded, the trypsinization at P2 resulted in 16 culture flasks, frozen in 12 cryotubes a concentration of $1 \times 10^{6} \mathrm{cel} / \mathrm{mL}$, placed in liquid nitrogen at $-196^{\circ} \mathrm{C}$.

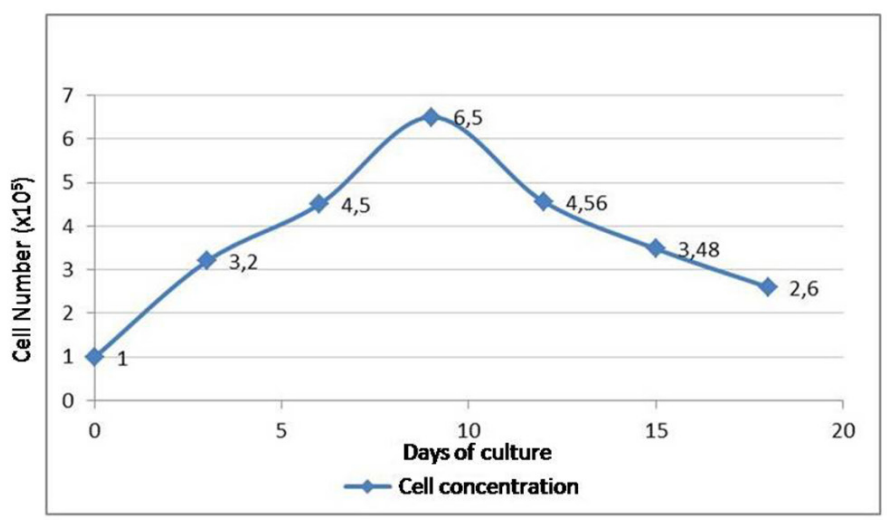

FIGURE 2 - Cell viability (\%) of progenitor cells from bone marrow of goat after eight passages in different days of culture.

\section{Flow cytometry}

The progenitor cells obtained from goat bone marrow aspirates were characterized for expression of markers Oct-3/4, Nanog, and Ck-Pan Vimentin by flow cytometry, which showed positive expression as observed in Figure 3.
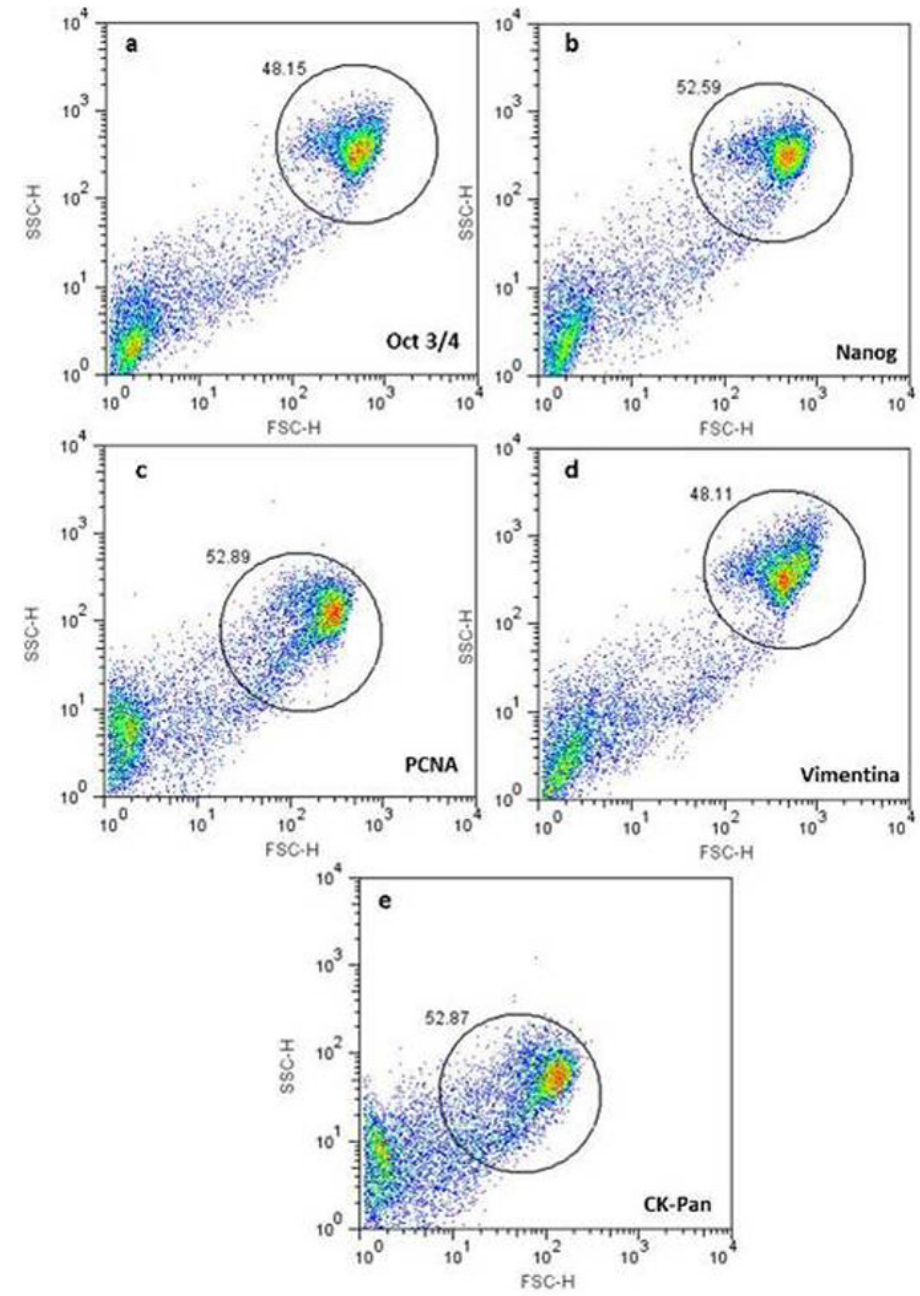

FIGURE 3 - Cell progenitor flow cytometry from goat bone marrow, showing positive expression for undifferentiated cell markers (A) OCT3/4 and (B) NANOG and the positive expression for PCNA cell proliferation (C) and the cytoskeleton for cell morphological identification Vimentine (D) and CK-PAN (E).

\section{Discussion}

\section{Cell culture}

Throughout our observations we found the presence of adherent cells, forming matrix cells that remained bonded after 72 hours culture, even after undergoing consecutive PBS washes. For the isolation method used to obtain bone marrow stem cells, our results were similar to Friedenstein et al. ${ }^{28}$, when they established the ability to adhere to plastic as a main feature, when suspension cells are washed two to four times a day, after the beginning of the culture. 
The primary culture was established by seeding a concentration of a bone marrow aspirate at $4.6 \times 10^{6}$ cells $/ \mathrm{mL}$ concentration, similar to that described by for MO primary rat cultures, using a cell concentration of $5 \times 10^{6}$ cells $/ \mathrm{mL}^{29}$. However, there are still differences in the behavior of MSC in vitro, given the wide range of cell concentrations used to obtain primary cultures from $1 \times 10^{6}$ cells $/ \mathrm{mL}^{30}$ to $7.5 \times 10^{6}$ cells $/ \mathrm{mL}^{31}$, in Dulbecco's Modified Eagle Medium, which showed similar results to ours.

A heterogeneous population of cells attached to the bottom of the culture flask began cell growth and this was observed until the eighth day of culture, but was gradually replaced by a more homogeneous population. Phinney et al. ${ }^{32}$ and Sekiya et al. ${ }^{33}$ demonstrated it with mice, in MSC isolation from bone marrow aspirates that resulted in a heterogeneous cell population with a high degree of hematopoietic contaminants that were subsequently removed by successive washes in PBS.

Otherwise, Tropel et al. ${ }^{34}$ observed a purified population only after 30 days of cultivation, while Meirelles and $\mathrm{Nardi}^{27}$ found similar results to ours. In fact, the time for obtaining homogeneous primary cultures from bone marrow aspirates is still controversial, since, according to the conditions of the medium, the cells lose their proliferative capacity ${ }^{35}$, which may explain differences in the time of obtaining purified or homogeneous populations in different experimental assays.

The fibroblastoid morphology observed in our in vitro studies showed morphology similar to that reported in cats ${ }^{36}$, as well as to descriptions of rodents and humans ${ }^{37}$. Tropel et al. ${ }^{34}$ found that such spindle shaped and fibroblastoid featured population became prominent in mice cultures, approximately two weeks after culture.

The potential for division in culture was measured by time in culture, verified by their growth curve, with the possibility of up to $99.36 \%$ in 15 passages. Similar assays were performed keeping rat bone marrow MCS cultured for 50 passages $^{27}$ and in cats for 25 passages $^{36}$.

\section{Flow cytometry}

Cell characterization based on flow cytometry revealed the presence of a cell population that expressed the octameric transcription factors (OCT-3/4), POU domain containing protein encoded by the Pou5fl gene. Scholer et al. ${ }^{38}$, Nichols et al. ${ }^{39}$ and Niwa et $a l .{ }^{40}$ described the transcription factor Oct-4 as essential regulator for the formation and/or maintenance of the inner cell mass (ICM) during pre-implantation development in rat embryonic cells. Studies by Loebel et al. ${ }^{41}$ and Tropel et al. ${ }^{34}$ demonstrated the selfrenewal capacity indefinitely in culture, as well as their potential to differentiate into specific cell types that holds great promise for regenerative medicine.

In our observations, the isolation of a positive OCT-3/4 population demonstrated the purification level achieved during successive passages in culture to MSC from bone marrow of goats native to the state of Piaui. Reports by Baddoo et al. ${ }^{42}$ demonstrated high expression of OCT-4 in MSC derived from rat bone marrow and these have shown great potential to differentiate to adipogenic, chondrogenic and osteogenic lineages. Similarly, Kerkis et al. ${ }^{43}$ identified a population of MSCs obtained from human dental pulp, which expressed embryonic stem cell markers such as Oct4, SSEA-3 and SSEA-4, with high plasticity to generate muscle tissue, neurons, cartilage and bone tissue and demonstrated the potential of obtaining these cells from other body sites.

The characterization essays performed for goat CMT showed that these cells also expressed the Nanog gene. Chambers et al. ${ }^{44}$ observed the action of the Nanog gene in the pluripotency regulation in the inner cell mass (ICM) during embryonic development. Pan and Thonsom ${ }^{45}$ showed that only the LIF/ OCT-4 pathway is insufficient to prevent cell differentiation events, suggesting that other factors could also be committed in the preservation of this feature. Mitsui et $a l .{ }^{46}$ found high concentrations of mRNA Nanog within the morula stage during embryonic development, and likewise, Tay et ll $^{47}$ found that in the absence of OCT-3/4 and LIF, Nanog is capable of maintaining a pluripotent cell. Riekstina et $a l .{ }^{48}$ reported the presence of embryonic stem cells markers such as OCT-4, Nanog, SOX 2 and SSEA-4 in the bone marrow as well as in cells isolated from adipose, heart and dermis tissues.

The ability to maintain in culture, beyond the immunophenotypic characteristics established by the International Society for Cellular Therapy, is one of the criteria for qualifying a population of cells as MSCs. The present study showed the positive expression of PCNA in cultures in fourth passage. In studies for cell therapy, the proliferative capacity has shown particular importance ${ }^{49}$. Morigi et al. ${ }^{50}$ used the Monoclonal Anti-Proliferating Cell Nuclear Antigen (anti-PCNA) to study renal cell repair in experimental models of acute kidney injury (AKI), and detected high PCNA expression in the renal tissue treated. Similarly, Gong and Niklason ${ }^{51}$, in studies with synthetic vascular prostheses, demonstrated positive staining by immunohistochemistry for PCNA. The use of bone marrow MSCs in the treatment of periodontal defects showed the presence of PCNA positive cells in the focus of injured tissue ${ }^{49}$.

Positive staining for both vimentin and CK-PAN helped in the characterization of the cell population found. Kurrey et 
al. ${ }^{52}$ and Elloul et al..$^{53}$ verified the presence of the expression of mesenchymal cell markers such as CD44, CD29, CD90 and coexpression with high participation for vimentin and Ck-Pan.

\section{Conclusions}

The plasticity of cell progenitors obtained from bone marrow aspirate from goats native to Piauí State. The expression of undifferentiated cells markers, typical of embryonic stem-cells, such as OCT-3/4, Nanog, cell proliferation markers (PCNA) and from mesenchymal cells (Vimentina and Ck-pan), associated to morphological and culture growth features, allowed us to suggest the existence of a MSC population in the studied goat bone marrow, which can be potentially explored in further pre-clinical studies.

\section{References}

1. Bussard AE, Pages J. Establishment of a permanent hybridoma producing a mouse autoantibody. Prog Clin Biol Res. 1978;26:16779. PubMed PMID: 570704.

2. Brockes JP. Amphibian limb regeneration: rebuilding a complex structure. Science. 1997 Apr 4;276(5309):81-7. PMID:9082990.

3. Wilmut I, Schnieke AE, McWhir J, Kind AJ, Campbell KH. Viable offspring derived from fetal and adult mammalian cells. Cloning Stem Cells. 2007 Spring;9(1):3-7. PMID: 17386005.

4. Lakshmipathy U, Verfaillie C. Stem cell plasticity. Blood Rev. 2005 Jan;19(1):29-38. PMID: 15572215.

5. Forbes SJ, Pamela VIG, Poulsom R, Wright NA, Alison MR. Adult stem cell plasticity: new pathways of tissue regeneration become visible. Clin Sci (Lond). 2002 Oct;103(4):355-69. PMID: 12241534.

6. Wagers A, Weissman I. Plasticity of adult stem cells. Cell. 2004 Mar 5;116(5):639-48. PMID: 15006347.

7. Jaiswal RK, Jaiswal N, Bruder SP, Mbalaviele G, Marshak DR, Pittenger MF. Adult human mesenchymal stem cell differentiation to the osteogenic or adipogenic lineage is regulated by mitogenactivated protein kinase. J Biol Chem. 2000 Mar 31;275(13):964552. PMID: 10734116.

8. Keller G. Embryonic stem cell differentiation: emergence of a new era in biology and medicine. Genes Dev. 2005 May 15;19(10):112955. PMID: 15905405.

9. Kratchmarova I, Blagoev B, Haack-Sorensen M, Kassem M, Mann M. Mechanism of divergent growth factor effects in mesenchymal stem cell differentiation. Science. 2005 Jun 3;308(5727):1472-7. PMID: 15933201.

10. Jiang Y, Jahagirdar BN, Reinhard TL. Pluripotency of mesenchymal stem cells derived from adult marrow. Nature. $2002 \mathrm{Jul}$ 4;418(6893):41-9. PMID: 12077603.

11. Rossi F, Cattaneo E. Opinion: neural stem cell therapy for neurological diseases: dreams and reality. Nat Rev Neurosci. 2002 May;3(5):401-9. PMID: 11988779.

12. Jeong SW, Chu K, Jung KH, Kim SU, Kim M, Roh JK. Human neural stem cell transplantation promotes functional recovery in rats with experimental intracerebral hemorrhage. Stroke. 2003 Sep;34(9):2258-63. PMID: 12881607.

13. Kim JH, Auerbach JM, Rodríguez-Gómez JA, Velasco I, Gavin D, Lumelsky N, Lee SH, Nguyen J, Sánchez-Pernaute R, Bankiewicz K, Mckay R. Dopamine neurons derived from embryonic stem cells function in an animal model of Parkinson's disease. Nature. 2002 Jul 4;418(6893):50-6. PMID: 12077607.

14. Lindvall O, Kokaia Z, Martinez-Serrano A. Stem cell therapy for human neurodegenerative disorders- how to make it work. Nat Med. 2004 Jul;10 Suppl:S42-50. PMID: 15272269.

15. Da Rocha AR, Alves FR, Neto NMA, Dos Santos LF, De Almeida HM, De Carvalho YKP, Bezerra DDO, Ferraz MS, Pessoa GT, De Carvalho MAM. Hematopoietic progenitor constituents and adherent cell progenitor morphology isolated from black-rumped agouti (Dasyprocta prymnolopha, Wagler 1831) bone marrow. Microsc Res Tech. 2012 Oct;75(10):1376-82. doi: 10.1002/jemt.22077.

16. Gotterbarm T, Breusch SJ, Schneider U, Jung M. The minipig model for experimental chondral and osteochondral defect repair in tissue engineering: retrospective analysis of 180 defects. Lab Anim. 2008 Jan;42(1):71-82. doi: 10.1258/la.2007.06029e.

17. Sampaolesi M, Blot S, D'antona G, Granger N, Tonlorenzi R, Innocenzi A, Mognol P, Thibaud JL, Galvez BG, Barthélémy I, Perani L, Mantero S, Guttinger M, Pansarasa O, Rinaldi C, De Angelis MGC, Torrente Y, Bordignon C, Bottinelli R, Cossu G. Mesoangioblast stem cells ameliorate muscle function in dystrophic dogs. Nature. 2006 Nov 30;444(7119):574-9. PMID: 17108972.

18. Alves FR, Santos TC, Freiberger S, Ambrósio CE, Miglino MA. Dinâmica dos precursores celulares do epitélio olfatório de cães sem raça definida: um estudo imunohistoquímico e ultra-estrutural. Pesq Vet Bras. 2007 Sept;27(9):388-92. doi: 10.1590/S0100-736X2007000900006.

19. Alves FR, Guerra RR, Fioretto ET, Delgado JC, Machado-Júnior AAN, Ambrósio CE, Kerkis I, Miglino MA. Establishment of a protocol for obtention of neuronal stem cells lineages from the dog olfactory epithelium. Pesq Vet Bras. 2010 Apr;30(4):363-72. doi: 10.1590/S0100-736X2010000400014.

20. Gaetani R, Barile L, Forte E, Chimenti I, Ionta V, Di Consiglio A, Miraldi F, Frati G, Messina E, Giacomello A. New perspectives to repair a broken heart. Cardiovasc Hematol Agents Med Chem. 2009 Apr;7(2):91-107. PMID: 19355872.

21. Feitosa MLT, Fadel L, Beltrão-Braga PCB, Wenceslau CV, Kerkis I, Kerkis A, Birgel-Júnior EH, Martins JFP, Martins DS, Miglino MA, Ambrósio CE. Successful transplant of mesenchymal stem cells in induced osteonecrosis of the ovine femoral head. Preliminary results. Acta Cir Bras. 2010 Oct;25(5):416-22. PMID: 20877951.

22. Fadel, Viana BR, Feitosa ML, Ercolin AC, Roballo KC, Casals JB, Pieri NC, Meirelles FV, Martins DS, Miglino MA, Ambrosio CE. Protocols for obtainment and isolation of two mesenchymal stem cell sources in sheep. Acta Cir Bras. 2011 Aug;26(4):267-73. PMID: 21808838.

23. Cunningham BW, Sefter JC, Hu N, McAfee PC. Autologous growth factors versus autogenous graft for anterior cervical interbody fusion: an in vivo caprine model. J Neurosurg Spine. 2010 Aug;13(2):21623. doi: 10.3171/2010.3.SPINE09512.

24. Vonk LA, Kroeze RJ, Doulabi BZ, Hoogendoorn RJ, Huang C, Helder MN, Everts V, Bank RA. Caprine articular, meniscus and intervertebral disc cartilage: An integral analysis of collagen network and chondrocytes. Matrix Biol. 2010 Apr;29(3):209-18. doi: 10.1016/j.matbio.2009.12.001.

25. Lechner F, Schütte A, Von-Bodungen U, Bertoni G, Pfister H, Jungi TW, Peterhans, E. Inducible nitric oxide synthase is expressed in joints of goats in the late stage of infection with caprine arthritis encephalitis virus. Clin Exp Immunol. 1999 Jul;117(1):70-5. PMID: 10403918.

26. Radostits OM, Gay CC, Hinchcliff KW, Constable PD. Veterinary medicine: a textbook of the disease of cattle, horses, sheep, pigs and goats. 10ed. Philadelphia: Saunders Elsevier; 2007.

27. Meirelles LS, Nardi NB. Murine marrow-derived mesenchymal stem cell: isolation, in vitro expansion, and characterization. $\mathrm{Br} \mathrm{J}$ Haematol. 2003 Nov;123(4):702-11. PMID: 14616976.

28. Friedenstein AJ, Gorskaja JF, Kulagina NN. Fibroblast precursors 
in normal and irradiated mouse hematopoietic organs. Exp Hematol. 1976 Sep;4(5):267-74. PMID: 976387.

29. Da Silva Meirelles L, Caplan AI, Nardi NB. In search of the in vivo identity of mesenchymal stem cells. Stem Cells. Stem Cells. 2008 Sep;26(9):2287-99. doi: 10.1634/stemcells.2007-1122.

30. Shahdadfar A, Fronsdal K, Haug T, Reinholt FP, Brinchmann JE. In vitro expansion of human mesenchymal stem cells: choice of serum is a determinant of cell proliferation, differentiation, gene expression, and transcriptome stability. Stem Cells. 2005 Oct;23(9):1357-66. PMID: 16081661

31. Carrancio S, Lopez-Holgado N, Sanchez-Guijo FM, Villaron E, Barbado V, Tabera S, Diez-Campelo M, Blanco J, San Miguel JF, Del Canizo MC. Optimization of mesenchymal stem cell expansion procedures by cell separation and culture conditions modification. Exp Hematol. 2008 Aug;36(8):1014-21. doi: 10.1016/j.exphem.2008.03.012.

32. Phinney DG, Kopen G, Isaacson RL, Prockop DJ. Plastic adherent stromal cells from the bone marrow of commonly used strains of inbred mice: Variation in yield, growth, and differentiation. J Cell Biochem. 1999 Mar 15;72(4):570-85. PMID: 10022616.

33. Sekiya I, Larson BL, Smith JR, Pochampally R, Cui JG, Prockop DJ. Expansion of human adult stem cells from bone marrow stroma: conditions that maximize the yields of early progenitors and evaluate their quality. Stem Cells. 2002;20(6):530-41. PMID: 12456961.

34. Tropel P, Noel D, Platet N, Legrand P, Benabid AL, Berger F. Isolation and characterization of mesenchymal stem cells from adult mouse bone marrow. Exp Cell Res. 2004 May 1;295(2):395-406. PMID: 15093739.

35. Banfi A, Muraglia A, Dozin B, Mastrogiacomo M, Cancedda R, Quarto R. Proliferation kinetics and differentiation potential of ex vivo expanded human bone marrow stromal cells: implications for their use in cell therapy. Exp Hematol. 2000 Jun;28(6):707-15. PMID: 10880757.

36. Martin DR, Cox NR, Hathcock TL, Niemeyer GP, Baker HJ. Isolation and characterization of multipotential mesenchymal stem cells from feline bone marrow. Exp Hematol. 2002 Aug;30(8):87986. PMID: 12160839 .

37. Woodbury D, Schwarz EJ, Prockop DJ, Black IB. Adult rat and human bone marrow stromal cells differentiate into neurons. J Neurosci Res. 2000 Aug 15;61(4):364-70. PMID: 10931522.

38. Scholer HR, Ruppert S, Suzuki N, Chowdhury K, Gruss P. New type of POU domain in germ line-specific protein Oct-4. Nature. 1990 Mar 29;344(6265):435-9. PMID: 1690859.

39. Nichols J. Formation of pluripotent stem cells in the mammalian embryo depends on the POU transcription factor Oct4. Cell. 1998 Oct 30;95(3):379-91. PMID: 9814708.

40. Niwa H, Miyazaki J, Smith AG. Quantitative expression of Oct-3/4 defines differentiation, dedifferentiation or self-renewal of ES cells. Nat Genet. 2000 Apr;24(4):372-6. PMID: 10742100.

41. Loebel DA, Watson CM, De young RA, Tam PP. Lineage choice and differentiation in mouse embryos and embryonic stem cells. Dev Biol. 2003 Dec 1;264(1):1-14. PMID: 14623228

42. Baddoo M, Hill K, Wilkinson R, Gaupp D, Hughes C, Kopen GC, Phinney DG. Characterization of mesenchymal stem cells isolated from murine bone marrow by negative selection. J Cell Biochem. 2003 Aug 15;89(6):1235-49. PMID: 12898521.

43. Kerkis I, Kerkis A, Dozortsev D, Stukart-parsons GC, GomesMassironi SM, Pereira LV, Caplan AI, Cerruti HF. Isolation and characterization of a population of immature dental pulp stem cells expressing OCT-4 and other embryonic stem cell markers. Cells Tissues Organs. 2006;184(3-4):105-16. PMID: 17409736.

44. Chambers I, Colby D, Robertson M, Nichols J, Lee S, Tweedie $\mathrm{S}$, Smith A. Functional expression cloning of Nanog, a pluripotency sustaining factor in embryonic stem cells. Cell. 2003 May 30;113(5):643-55. PMID: 12787505.

45. Pan G, Thomson JA. Nanog and transcriptional networks in embryonic stem cell pluripotency. Cell Res. 2007 Jan;17(1):42-9. PMID: 17211451.

46. Mitsui $\mathrm{K}$, Tokuzawa $\mathrm{Y}$, Itoh $\mathrm{H}$. The homeoprotein Nanog is required for maintenance of pluripotency in mouse epiblast and ES cells. Cell. 2003 May 30;113(5):631-42. PMID: 12787504.

47. Tay Y, Zhang J, Thomson AM, Lim B, Rigoutsos I. MicroRNAs to Nanog, Oct4 and Sox 2 coding regions modulate embryonic stem cell differentiation. Nature. 2008 Oct 23;455(7216):1124-8. doi: 10.1038/nature07299.

48. Riekstina U, Cakstina I, Parfejevs V, Hoogduijn M, Jankovskis G, Muiznieks I, Muceniece R, Ancans J. Embryonic stem cell marker expression pattern in human mesenchymal stem cells derived from bone marrow, adipose tissue, heart and dermis. Stem Cell Rev. 2009 Dec;5(4):378-86. doi: 10.1007/s12015-009-9094-9.

49. Hasegawa K, Fujioka T, Nakamura Y, Nakatsuji N, Suemori H. A method for the selection of human embryonic stem cell sublines with high replating efficiency after single-cell dissociation. Stem Cells. 2006 Dec;24(12):2649-60. PMID: 16931777.

50. Morigi M, Imberti B, Zoja C, Corna D, Tomasoni S, Abbate M, Rottoli D, Angioletti S, Benigni A, Perico N, Alison M, Remuzzi G. Mesenchymal stem cells are renotropic, helping to repair the kidney and improve function in acute renal failure. J Am Soc Nephrol. 2004 Jul;15(7):1794-804. PMID: 15213267.

51. Gong Z, Niklason LE. Small-diameter human vessel wall engineered from bone marrow-derived mesenchymal stem cells (hMSCs) FASEB J. 2008 Jun;22(6):1635-48. doi: 10.1096/fj.07-087924.

52. Kurrey KA, Bapat SA. Snail and Slug aremajor determinants of ovarian cancer invasiveness at the transcription level. Gynecol Oncol. 2005 Apr;97(1):155-65. PMID: 15790452.

53. Elloul S, Silins CG, Trope AB, Davidson B, Reich R. Expression of E-cadherin transcriptional regulators in ovarian carcinoma. Virchows Arch. 2006 Nov;449(5):520-8. PMID: 17024425.

\section{Acknowledgements}

To Sao Paulo University School of Veterinary Medicine and Zootechnology (FMVZ/USP), and the Animal Sciences and Morphological Research Lab. (CCA/UFPI).

\section{Correspondence:}

Prof. Dr. Flávio Ribeiro Alves

Universidade Federal do Piaú

Departamento de Morfofisiologia Veterinária

Campus Universitário

Ministro Petrônio Portella

64049-550 Teresina - PI Brasil

Tel.: (55 86)3215-5753

flavioribeiro@ufpi.edu.br

Received: Mar 10, 2014

Review: May 12, 2014

Accepted: Jun 11, 2014

Conflict of interest: none

Financial source: National Council for Scientific and Technological Development (CNPq)

${ }^{1}$ Research performed at Morphophysiology Laboratory, Federal University of Piaui (UFPI), Teresina-PI, Brazil. 